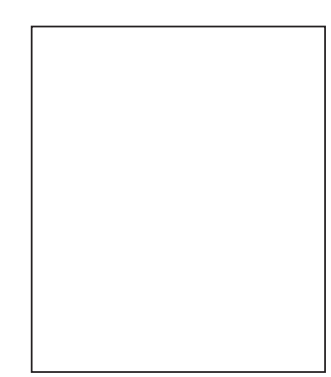

\title{
Työelämä ja aikuiskoulutuspolitiikka
}

\author{
Julkisuudessa yritysjohtajat puhuvat "ihmisestä työpaikan \\ tärkeimpänä voimavarana“. Myös monet aikuiskasvatuksen \\ ammattilaiset tähdentävät henkilöstön kouluttamisen \\ välttämättömyyttä kilpailussa menestymiseksi. Kilpailun paineissa \\ yritykset soveltavat uusia innovaatioita myös työvoimaansa, mutta \\ missä määrin henkilöstövoimavarojen jatkuva kehittäminen ja \\ ihmisten potentiaalien hyödyntäminen voivat toteutua ikään kuin \\ luonnostaan markkinavoimien pakottamana? Artikkelissa tätä \\ kysymystä arvioidaan lähinnä työelämän koulutusta koskevien \\ tilastotietojen avulla.
}

Aikuiskoulutuspolitiikan periaatteiksi kirjattiin vuosikymmeniä sitten koulutuksellisen tasa-arvon lisääminen, tuotannon edistäminen työntekijöiden ammattitaitoja kehittämällä, demokratian edistäminen kansalaisten yhteiskunnallisia valmiuksia kehittämällä sekä kulttuurin jatkuvuus ja uudistaminen inmisten persoonallisuutta kehittämällä (Lehtisalo \& Raivola 1992, 135--138). Näiden tavoitteiden arvoa ei sinänsä kiistä kukaan, mutta käytännössä niitä ei kuitenkaan saada hevin toteutettua yhtäaikaisesti.

Ristiriita palautuu paljolti siihen, että yksilön "kasvutarpeita" korostavia perusteluja ja tuotannon edistämistä korostavia perusteluja on vaikea sovittaa yhteen. K iivastahtinen ja mo- nella tapaa turvaton työelämä ei ole välttämättä suotuisa paikka henkiselle kasvulle. Pelkästään yhteiskunnallisista perusteluista (kuten tuotantoelämän tarpeista) johdettu politiikka koetaan helposti epähumaaniksi, inmisen alistamisena välineeksi. Toisaalta yksinomaan yksilöllisen kasvun tavoitteista johdettu koulutuspolitiikkaa jää helposti vain voimattomaksi julistukseksi. (Lampinen 1998, 147-148.) K äytännössä yhteiskunnan eri intressiryhmillä onkin selvästi erilaiset preferenssit omissa koulutuspolitiikoissaan. Työntekijöillä, työnantajilla ja julkisella vallalla on kullakin oma näkökulmansa koulutukseen ja sen tehtäviin.

Työnantajat nivovat koulutustoimintansa muun henkilöstöhallinnon päämääriin. K äy- 
tännössä rajanveto koulutuksen ja monien muiden "henkilöstön kehittämisen" muotojen välillä on vaikeaa eikä esimerkiksi yritysjohdon näkökulmasta tarpeellistakaan (esim. Mulder 1990 ja 1992; Bowers 1993). Henkilöstökoulutuksen perimmäisten tavoitteiden voi sanoa säilyneen samoina vuosikymmeniä: (1) tehostaa toimintaa edelleen ja (2) luoda sosiaalista kiinteyttä sekä näiden yhteisvaikutuksena (3) kohentaa taloudellisuutta ja lisätä tuottavuutta (ks. esim. Mäki 1964; Tuomisto 1986). "In a business sense, investment in human capital seeks a measurable and positive end result in enhanced business profits", kuten Blomberg (1989) sanoo.

Tuottavuuden ja kilpailukyvyn paranemista sekä muita vaikutuksia mitattaessa vaakakupissa ovat koulutuksesta aiheutuvat kustannukset. $\mathrm{N}$ iihin kuuluu suoranaisten koulutuskulujen lisäksi olennaisena kustannuseränä työaika, jonka koulutettavat ja kouluttajat ovat poissa tuotannosta. K oulutuksen rahallisia hyötyjä vakavasti tavoitteleva yritys laskee myös koulutuksen vaihtoehtoiskustannukset. Liiketaloudellisesta näkökulmasta yrityksen kannattaa kouluttaa henkilöstöään, jos saavutetut rajahyödyt ovat vähintään panostettujen rajakustannusten suuruiset. (Esim. Taylor 1987; Blomberg 1989.) Se on toinen asia, kuinka monella työpaikalla hyötyjä arvioidaan etukäteen mitenkin tarkkaan.

Esimerkiksi Vahervan kokemusten mukaan yritysjohtokaan ei ole aina ajatellut koulutuksen tarvetta loppuun asti, eikä tiedostanut, mitä oikein odottaa koulutukselta. Varsinkin pienet ja keskisuuret yritykset turvautuvat yleisesti ulkopuolisiin kurssi- ja konsulttipalveluihin, joiden huoleksi koulutus jätetään. K ouluttajien itsearvioinnit ja koulutettavien haastattelut kuitenkin osoittavat, että työpaikoilla kaikenlaiseen opetukseen ollaan yleensä tyytyväisiä. Sen sijaan asiantuntijoiden ja tutkijoiden koulutukselle asettamat arviointikriteerit ovat vaativimmat, eikä koulutus ole niillä arvioiden aina kovinkaan laadukasta. "Mutta opetustapahtuman varsinaiset osapuolet ovat tyytyväisiä sehän lienee kuitenkin tärkeintä!", Vaherva
(1993, 122-123) huudahtaa sarkastisesti.

K oulutuksen vaikuttavuuden arviointi on sen verran vaikeaa, että se jätetään usein tekemättä. Silloinkin kun vaikuttavuutta yritetään arvioida, taloudellisten hyötyjen asemesta mitataan helpommin mitattavia asioita. K uten Rainer $A$ altonen muistuttaa, niin aineellisten kuin ei-aineellisten vaikutusten mittaaminen edellyttää tutkimusasetelmia, jotka mahdollistavat kausaalipäätelmien teon. Sen lisäksi mittaus on kohdistettava niihin asioihin, joihin koulutuksella halutaan vaikuttaa. Esimerkiksi myönteisistä koulutuskokemuksista ei voida päätellä varsinaisia oppimistuloksia, eikä hyvistäkään oppimistuloksista voi päätellä taloudellisia hyötyjä. K oulutuksen taloudellisten vaikutusten arviointiin voidaan päästä käsiksi vasta, kun tutkitaan taloudellista arvoa luovaa tekijää eli työtä. (A altonen 1989, 165.) A rvioitujen hyötyjen suuruus riippuu tietenkin myös siitä, millä aikavälillä vaikutuksia mitataan. K aikki vaikutukset eivät todellistu lisääntyneenä tuottavuutena heti koulutusjakson päätyttyä.

A rvioinnin mielekäs aikaväli puolestaan riippuu mittauksen kohteena olevien kompetenssien luonteesta (Nordhaug 1991; Lowyck 1996). Koulutuksen ansiosta kohentuneet tekniset kompetenssit (esimerkiksi uusien työvälineiden käyttötaidot) voivat tuottaa tulosta aika nopeastikin. Sen sijaan monien niin kutsuttujen metakompetenssien (esimerkiksi ongelmanratkaisukyvyt, muutoksen hallinta) kehittyminen näkyy usein vasta pidemmällä aikavälillä. 0 dotukset vaikutusten nopeudesta heijastuvat järjestettävän koulutuksen luonteeseen. K un odotukset kohdistuvat ensi sijassa välittömästi koulutuksen jälkeen ilmeneviin vaikutuksiin, investointia metakompetenssien tyyppisten yleistaitojen kehittämiseen ei nähdä kannattavaksi.

Tutkimustulosten mukaan siirtovaikutus formaalista koulutuksesta työhön on kaiken kaikkiaan vähäinen, kun enimmilläänkin vain noin kolmannes ulkopuolisessa koulutuksessa opitusta siirtyy käyttövalmiuksiksi työhön (ks. Vaherva 1998, 171-172). 


\section{Työpaikan tärkein voimavara?}

1980-luku oli kasvun aikaa työelämänkin koulutuksessa. Vuosikymmenen alussa työnantajat kouluttivat noin puolta miljoonaa suomalaista vuodessa. Vuonna 1989 henkilöstökoulutuksessa oli jo 900000 inmistä. Vastaavasti koulutuksessa olleiden osuus koko palkansaajakun-nasta nousi 1980 -luvulla 29 prosentista 44 prosenttiin. Koko palkansaajakunnan koulutuspäivien määrä lisääntyi vuoden 1982 neljästä miljoonasta viiteen ja puoleen miljoonaan vuonna 1989.

1990-luvulle tultaessa kouluttaminen taas väheni usealla sadallatuhannella palkansaajalla. K oulutuksessa vuosittain olleiden määrä supistui vuoden 1989 tasosta noin neljänneksellä vuoteen 1993 tultaessa. M yös koulutuspäivien kokonaismäärä väheni vastaavana aikana lähes yhtä paljon. Vuonna 1993 henkilöstökoulutuspäivien kokonaismäärä oli 1980-luvun alkuvuosien lukemissa. On toki huomattava, että potentiaalisten koulutettavien eli työllisten määrä oli niin ikään vähentynyt olennaisesti.
H enkilöstökoulutus noudattaa tiettyjä, muun muassa yrityskokoon ja toimialaan, omistajatyyppiin sekä organisaation hierarkiaan liittyviä säännönmukaisuuksia (esim. Bishop 1990; OECD 1991; Kalleberg 1992; Rinne ym. 1995).

Ensinnäkin yrityksen koko on olennainen henkilöstökoulutuspolitiikkaa luonnehtiva rakenteellinen tekijä. Palkansaajan osallistumistodennäköisyys henkilöstökoulutukseen kasvaa melko lineaarisesti yrityksen koon mukaan. Esimerkiksi henkilöstökoulutuksen aktiivisimpana aikana vuonna 1990 alle kymmenen hengen yrityksissä työskentelevistä koulutettiin joka neljättä. Toisaalla yli 500 hengen yrityksessä työskentelevistä joka toinen oli henkilöstökoulutuksessa vuoden aikana. (H eikkinen 1993, liite.)

Toinen keskeinen piirre henkilöstökoulutuksessa on se, että julkiset työnantajat kouluttavat henkilöstöään laajemmin kuin yksityiset yritykset. Julkisen sektorin työllistämän sosiaali- ja terveydenhuollon sekä opetusalan henkilöstön osallistuminen henkilöstökoulutukseen selittyy

TAULUKKO 1. Henkilöstökoulutettujen osuus palkansaajista ja koulutuspäivien määrä sosioekonomisen aseman mukaan vuosina 1982-1996

\begin{tabular}{|c|c|}
\hline $\mathrm{N}$ & PÄIVIEN MÄÄRÄ \\
\hline SALLISTUNEET & SAAJAA KOHTI \\
\hline
\end{tabular}

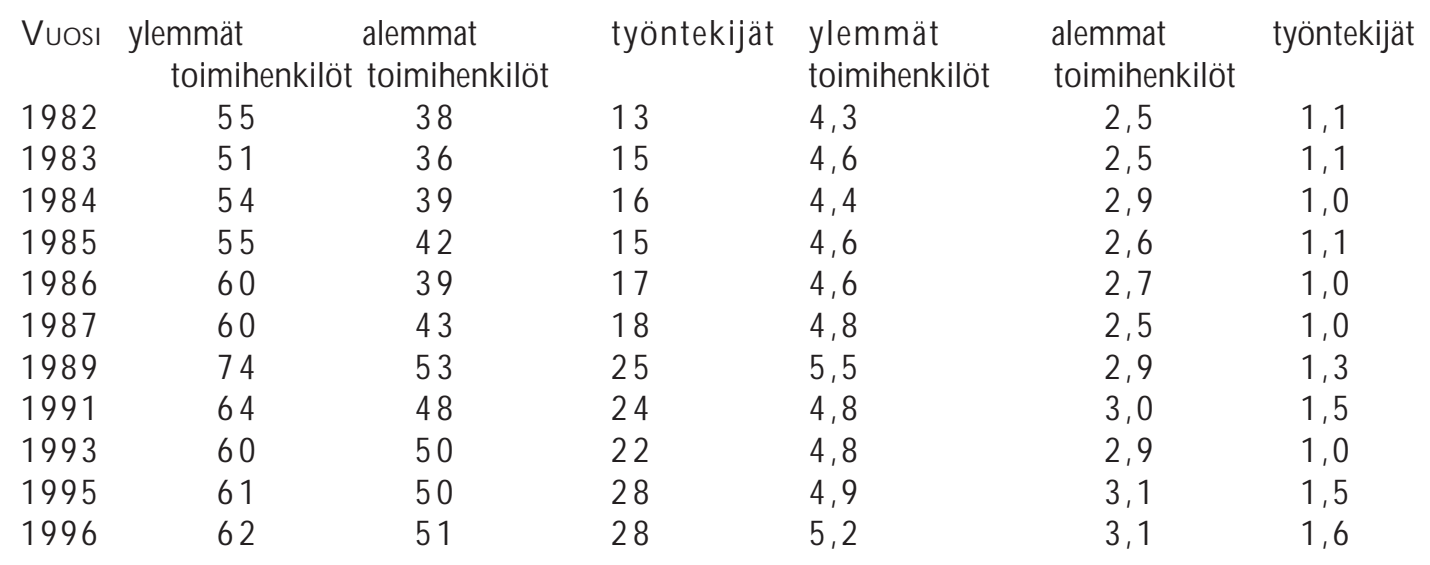

Lähteet: Tilastokeskus, henkilöstökoulutustilastot. 
paljolti koulutuksen sidonnaisuudesta lainsäädäntöön, virkaehtosopimuksiin ja tunnollisesti noudatettuihin suosituksiin.

K olmas tärkeä henkilöstökoulutusta muot oava tekijä on organisaation hierarkiarakenne. K orkealle hierarkiassa sijoitettuja koulutetaan työelämässä eniten (taulukko 1). H enkilöstökoulutus noudattaa vahvasti kasautumisen periaatetta (esim. Wholey 1990; Altonji \& Spletzer 1991). Työelämän koulutustoiminnassa ei siis ole ensisijaisesti kysymys siitä, että työnantajat joutuisivat ikään kuin taloudellisesta välttämättömyydestä kouluttamaan heikosti koulutettua työvoimaansa. Henkilöstökoulutus kasautuu pitkälle koulutetuille ja muutenkin etuoikeu-tetuissa asemissa oleville.

K ouluttaminen yleistyi 1980-luvulla koskemaan lähes kaikkia ylempiä toimihenkilöitä. K un vuonna 1983 koulutuksessa oli joka toinen ylempi toimihenkilö, vuonna 1989 koulutettiin peräti kolmea neljästä. Vastaavana aikana alempien toimihenkilöiden kouluttaminen lisääntyi kolmanneksesta reiluun puoleen ja työntekijöiden kahdeksasosasta neljäsosaan.

1990-luvun lama-aikana ylempien toimihenkilöiden koulutusosuus näyttää vähenneen selvästi enemmän kuin alempien toimihenkilöiden tai työntekijöiden osuudet. Tässä katsannossa sosioekonomisten ryhmien väliset erot kaventuivat syvän taantuman vuosina. O lennaista on kuitenkin huomata se, ettei koulutusosuuksien kaventuneiden erojen syynä ole työelämän koulutuspolitiikan "tasa-arvoistuminen", vaan ennen kaikkea palkansaajakunnan rakenteelliset muutokset.

Pelkästään koulutusta saaneiden osuuksina kuvatut muutokset eivät kerro henkilöstökoulutuksen koko totuutta kasvaneiden työttömyyslukujen ja laman oloissa. Esimerkiksi kun koulutuspäivien määrä suhteutetaan palkansaajaryhmien kokoon, erot asemien välillä näkyvät selvinä. Y lempien toimihenkilöiden ja työntekijöiden välinen osallistumisero ei kaventunut työntekijöiden koulutuspäivien lisääntymisen vuoksi, vaan siksi, että työntekijät kerta kaik- kiaan vähenivät - työpaikoilta työttömyyskortistoon. Työntekijöitä oli henkilöstökoulutuksessa vuonna 1993 peräti 39 prosenttia vähemmän kuin vuonna 1989. (Rinne ym. 1995, 146-147.)

Henkilöstökoulutuksen määrällistä muutosta kuvaa ehkä vieläkin osuvammin koulutukseen käytetyn yhteenlasketun ajan vaihtelu työelämän hierarkian eri tasoilla. Alempien toimihenkilöiden koulutuspäivien kokonaismäärä väheni vuosina 1989-93 suhteellisesti suunnilleen saman verran kuin palkansaajienkin määrä. Sen sijaan sekä ylempien toimihenkilöiden että työntekijöiden koulutuspäiviä vähennettiin selvästi enemmän kuin palkansaajien lukumäärän vähennys antaisi odottaa. Vuosien 1989- 1993 välillä koulutuspäivien kokonaismäärää supistettiin ylemmällä toimi-henkilötasolla 11 prosenttia, alemmalla toimi-henkilötasolla $17 \mathrm{ja}$ työntekijätasolla 52 prosenttia.

Palkansaajien, henkilöstökoulutettujen ja koulutuspäivien määrien muutokset noudattavat siis melko säännönmukaisesti työelämän hierarkiarakenteita. Suurimmat supistukset koettelivat työntekijätasoa kaikilla mittareilla mitaten. $V$ ähiten puututtiin ylempään toimihenkilötasoon.

Koulutettujen osuudella mitaten henkilöstökoulutuksen kärkiryhmään kuuluvat sellaiset korkean statuksen ammatit kuin oppilaitosten rehtorit ja korkeakouluopettajat, lääkärit sekä julkisen hallinnon johtajat ja toimitusjohtajat. $\mathrm{N}$ äissä ammattiryhmissä työskenteleviä koulutetaan yleensä lähes kaikkia. V ähiten koulutettujen ryhmät löytyvät odotetusti työläisammateista. Talouden kannalta hyvänäkin vuotena 1989 esimerkiksi talonrakentajista vain kuusi prosenttia oli työnantajan kustantamassa koulutuksessa. Tekstiili- ja jalkinetyössä, kumi- ja muovityössä sekä lasi- ja kivityössä koulutettiin vain joka kymmenettä työntekijää. Heidän koulutusosuutensa eivät ole tietenkään Iaman aikana nousseet. Laman alkaessa kaikkein alim-mas jäivät maalarit, joista vain neljä prosenttia oli ollut koulutuksessa vuonna 1991. (Rinne ym. 1995.)

\section{AIKUISKASVATUS 4/98}


TAULUKKO 2. Palkansaajan arvio työpaikkansa koulutusmahdollisuuksista sukupuolen ja sosioekonomisen aseman mukaan (\%)

K OULUTUSMAHDOLLISUUdET TYÖPAIKalLA

\begin{tabular}{|c|c|c|c|c|c|c|c|}
\hline \multirow{3}{*}{ Y LEMMÄT } & & H yvät & K ohtalaiset & H eikot & E i osaa sanoa & $\mathrm{N}$ & \\
\hline & TOIMIHENKILÖT & 37 & 41 & 20 & 2 & 396 & 000 \\
\hline & Miehet & 43 & 39 & 16 & 2 & 229 & 000 \\
\hline & $\mathrm{N}$ aiset & 29 & 44 & 26 & 1 & 167 & 000 \\
\hline \multirow[t]{3}{*}{ AlEMMAT } & TOIMIHENKILÖT & 26 & 40 & 31 & 2 & 628 & 000 \\
\hline & Miehet & 30 & 39 & 29 & 2 & 170 & 000 \\
\hline & $\mathrm{N}$ aiset & 25 & 41 & 32 & 3 & 458 & 000 \\
\hline \multirow[t]{3}{*}{ TYÖNTEKIJ } & & 13 & 33 & 50 & 5 & 585 & 000 \\
\hline & M iehet & 15 & 32 & 49 & 4 & 408 & 000 \\
\hline & $\mathrm{N}$ aiset & 9 & 35 & 52 & 5 & 177 & 000 \\
\hline \multirow[t]{2}{*}{ KAIKKI } & M iehet & 26 & 36 & 35 & 3 & 808 & 000 \\
\hline & $\mathrm{N}$ aiset & 22 & 40 & 35 & 3 & 802 & 000 \\
\hline
\end{tabular}

AKU95-haastattelussa koulutusmahdollisuuksia kysyttiin seuraavasti: "O nko Teillä työpaikallanne (1) hyvät, (2) kohtalaiset, vai (3) heikot mahdollisuudet saada ammattitaitoanne kehittävää tai uraanne edistävää koulutusta?"

Samat työelämän hierarkiarakenteet ja työnantajien koulutuspreferenssit heijastuvat myös palkansaajien käsityksiin työpaikan koulutustarjonnasta. M yös vaikutusmahdollisuudet siihen, millaista koulutusta työpaikalla tarjotaan, myötäilevät sosiaalista hierarkiaa (Blomqvist ym. 1997, 30). Henkilöstön kehittämisessä koetut monet ongelmat kytkeytyvät tavallisesti juuri työntekijöiden vähäisiin vaikutusmahdollisuuksiin. Mitä paremmat vaikutus- ja osallistumismahdollisuudet työntekijöillä on, sitä todennäköisemmin he myös kiinnostuvat ja sitoutuvat työpaikan kehittämistoimintaan. (J uhela 1996.)

Tilastokeskuksen Aikuiskoulutus 1995 -haastatteluaineiston (A ku-95) mukaan neljäsosa palkansaajista pitää oman työpaikkansa koulutusmahdollisuuksia hyvinä (taulukko 2). $M$ ahdollisuudet vaihtelevat huomattavasti palkansaajaryhmittäin. Parhaat mahdollisuudet on ylemmillä toimihenkilömiehillä ja huonoimmat työntekijätason naisilla. Lukumääriksi muutettuna osuudet tarkoittavat, että hyvien koulutusmahdollisuuksien asemissa on Suomessa kaiken kaikkiaan vajaat 400000 ja huonojen koulutusmahdollisuuksien asemissa lähes 600000 palkansaajaa.
Henkilöstökoulutukseen osallistumista ja koulutusmahdollisuuksia kuvaavien tilastotietojen perusteella työpaikan tärkein voimavara näyttävät olevan tyypillisesti johtotehtävien (ylemmät) toimihenkilöt.

\section{Koulutuksen välttämättömyys?}

Työelämän koulutusta kuvaavia tilastoja tarkasteltaessa on muistettava, että osa työntekijöistä ei ole itsekään kiinnostunut työpaikan koulutustoiminnasta. Työpaikkansa koulutustarjontaa huonona pitävät eivät välttämättä osallistuisi koulutukseen, vaikka sitä olisi tarjollakin. Huonoiksi arvioiduista koulutusmahdollisuuksista ei siis seuraa, että parempi tarjonta olisi sen enempää työnantajan kuin työntekijän mielestä tarpeellista tai välttämätöntä, jotta työtehtävät tulisivat hoidettua paremmin.

Selvästi suurimmalla osalla palkansaajakuntaa töiden oppiminen vie korkeintaan joitakin kuukausia (taulukko 3). Työn vaatima oppiaika Iyhenee yllättävänkin säännönmukaisesti työelämän hierarkiassa alaspäin mentäessä. N iin ikään sukupuolten väliset erot ovat huomatta- 


\section{ARाIKस}

TAULUKKO 3. Työn oppimisaika palkansaajan sosioekonomisen aseman, toimialan ja sukupuolen mukaan vuonna 1995(\%)

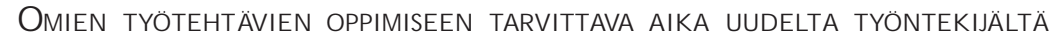

\begin{tabular}{|c|c|c|c|c|c|c|c|}
\hline & $\begin{array}{l}\text { Joitakin } \\
\text { tunteja }\end{array}$ & $\begin{array}{l}\text { Joitakin } \\
\text { päiviä }\end{array}$ & $\begin{array}{l}\text { Joitakin } \\
\text { viikkoja }\end{array}$ & $\begin{array}{l}\text { Joitakin } \\
\text { kuukausia }\end{array}$ & $\begin{array}{l}1-2 \\
\text { vuotta }\end{array}$ & $\begin{array}{l}\text { Yli } 2 \\
\text { vuotta }\end{array}$ & $\mathrm{N}$ \\
\hline YLEMMÄT & 2 & 3 & 12 & 27 & 35 & 22 & 386000 \\
\hline \multicolumn{8}{|l|}{ TOIMIHENKILÖT } \\
\hline Miehet & 2 & 2 & 8 & 25 & 37 & 25 & 222000 \\
\hline$N$ aiset & 3 & 3 & 17 & 28 & 32 & 16 & 163000 \\
\hline \multicolumn{8}{|l|}{ Alemmat } \\
\hline TOIMIHENKILÖT & 2 & 9 & 24 & 33 & 22 & 9 & 621000 \\
\hline Miehet & 1 & 3 & 16 & 27 & 32 & 21 & 168000 \\
\hline$N$ aiset & 3 & 11 & 27 & 36 & 19 & 5 & 453000 \\
\hline TYÖNTEKIJÄT & 4 & 17 & 26 & 25 & 18 & 10 & 577000 \\
\hline Miehet & 3 & 12 & 23 & 26 & 22 & 13 & 404000 \\
\hline $\mathrm{N}$ aiset & 6 & 29 & 36 & 23 & 6 & 0 & 173000 \\
\hline \multicolumn{8}{|l|}{ KAIKKI } \\
\hline Miehet & 2 & 8 & 17 & 26 & 29 & 18 & 795000 \\
\hline $\mathrm{N}$ aiset & 4 & 13 & 27 & 31 & 19 & 6 & 789000 \\
\hline
\end{tabular}

AKU 95-haastattelussa oppiaikaa kysyttiin seuraavasti: "Kuinka kauan omien työtehtävienne kokonaisuuden oppiminen veisi mielestänne aikaa uudelta työntekijältä, jolla on tarvittava pohjakoulutus?" Vastausvaihto ehdot olivat: (1) joitakin tunteja, (2) joitakin päiviä, (3) joitakin viikkoja, (4) joitakin kuukausia, (5) 12 vuotta, (6) yli 2 vuotta., (7) ei osaa sanoa. "Ei osaa sanoa"-vastaukset jätetty pois analyysistä.

vat. Miehet arvioivat töidensä vaativan enemmän oppiaikaa kuin naiset. O letettavasti miehet ja naiset mieltävät työn oppiaikaa mittaavan kysymyksen jossain määrin eri tavoin, ja vastaukset kuvastavat osittain myös erilaista oman työn arvostusta, ei vain tosiasiallisia eroja työn vaativuudessa (Lehto 1996, 103; N aumanen 1994, 192). Toki arviot kuvaavat asemien välisiä todellisia eroja työn sisällöissä ainakin summittaisesti.

Arvioitu oppiaika vaihtelee olennaisesti myös toimialoittain (Silvennoinen 1998). Yhtäällä ovat jalostustoimialojen ylemmät miestoimihenkilöt, joista joka kolmannelta työn oppiminen tehtäviin vie yli kaksi vuotta. Toisaalla palvelualoilla kolme naistyöntekijää neljästä arvioi, että heidän työnsä oppii muutamassa viikossa. Joka kolmannen naistyöntekijän työt oppii muutamassa päivässä.

M uutamassa viikossa opittavaa työtä voi pitää työntekijän voimavarojen alihyödyntämisenä. Sen perusteella voidaan arvioida, että lähes 600000 inmisen voimavarat ovat suorastaan laiminlyödyt suomalaisessa työelämässä. Jos muutamassa kuukaudessa opittavaa työtä pidetään vaatimattomana, päädytään arvioon, jonka mukaan noin miljoonan palkansaajan osaamiskapasiteetti on vajaakäytössä.

Työnantajan näkökulmassa tehdyn työn määrä onkin sisältöä tärkeämpi. Tilastokeskuksen työolotutkimusten mukaan kiire suomalaisilla työpaikoilla on kasvanut melko tasaisesti kahdenkymmenen viime vuoden aikana. $\mathrm{K}$ iire haittaa erityisesti tulosohjatuilla työpaikoilla sekä tiimityössä. EU-maiden keskinäisessä vertailussa vuodelta 1996 Suomi osoittautui kiireisimmän työelämän maaksi: joka kolmas meikäläinen valittaa, ettei työn tekemiseen anneta tarpeeksi aikaa. (Lehto 1998.) Tässä katsannossa suomalaisen työelämän voi sanoa toimivan tehokkaasti: niukka henkilöstö tekee ko- 
valla kiireellä yrityksille ennen näkemättömän voitollista tulosta.

Vaikka valtaosa palkansaajista pitää työtään sisällöltään aika vaatimattomana, kaikkeen työhön liittyy aina jonkinlaista oppimista. Sisällöllisesti antoisissa töissä ammattitaidot kehittyvät ja osaaminen kohenee jatkuvasti. K ykyjen minimikäytön periaatteen mukaan organisoiduissa töissä taas opitaan sopeutumaan ulkoapäin tulevaan kontrolliin ja epäautonomisuuteen sekä sietämään yksitoikkoisia tehtäviä.

Voidaan ajatella, että työn vaativuuden ja tekijän osaamisen välillä on koetun mielekkyyden ja työtyytyväisyyden kannalta jonkinlainen teoreettinen optimi: yhtäältä liian vaatimaton ja toisaalta liian vaativa tehtävä on työtyytyväisyyden ja sitoutumisen kannalta negatiivista (esimerkiksi Spector 1986; Mottaz 1987). Toisaalta esimerkiksi Thångin (1995) havaintojen mukaan yksitoikkoinen ja toistoluonteinen työ ei kuitenkaan välttämättä käynnistä halua vaihtaa "parempiin" töihin. I hminen voi oppia tekemään aika tyytyväisenä yksitoikkoisiakin rutiineja. Rajoittavissakin oloissa työntekijät riipivät kokoon välttämättömät ainekset toiminnan mielekkyyden ylläpitämiseksi, kuten Julkunen $(1987,156)$ sanoo.

Valtaosa suomalaisista palkansaajista arvioi, että heidän työtehtävänsä ja valmiutensa vastaavat hyvin toisiaan, eivätkä he tarvitse lisää koulutusta tehtäviinsä. Tulos voidaan tulkita niinkin, että työntekijöillä on kapea käsitys koulutuksen mahdollisuuksista esimerkiksi työn mielekkyyden lisääjänä (Vaherva 1995). Vain joka kuudes palkansaaja katsoo, että selviytyäkseen hyvin tehtävistään, hän tarvitsee lisää koulutusta. Toisaalta suunnilleen yhtä moni pitää tehtäviään valmiuksiinsa nähden liian yksinkertai-sina. Lisäkoulutuksen tarve työ-

TAULUKKO 4. Palkansaajan arvio omista valmiuksistaan nykyisiin työtehtäviinsä sukupuo len ja sosioekonomisen aseman mukaan (\%)

\begin{tabular}{|c|c|}
\hline $\begin{array}{l}\text { arvitsee } \\
\text { isäkoulutusta }\end{array}$ & $\begin{array}{l}\text { Tehtävät vastaavat Tehtävät liian } \\
\text { valmiuksia } \\
\text { yksinkertaisia }\end{array}$ \\
\hline
\end{tabular}

Y LEMMÄT

$\begin{array}{llllll}\text { TOIMIHENKILÖT } & 22 & 69 & 9 & 395000 \\ \text { M iehet } & 23 & 68 & 9 & 228000 \\ \text { N aiset } & 21 & 70 & 9 & 166000 \\ \text { ALEMMAT } & & & & & \\ \text { TOIMIHENKILÖT } & 19 & 64 & 17 & 625000 \\ \text { M iehet } & 18 & 71 & 11 & 170000 \\ \text { N aiset } & 20 & 61 & 19 & 455000 \\ \text { TYÖNTEKIJÄT } & 11 & 69 & 20 & 579000 \\ \text { M iehet } & 12 & 69 & 19 & 405000 \\ \text { N aiset } & 8 & 67 & 24 & 174000 \\ \text { KaIKKI } & & & & & \\ \text { M iehet } & 17 & 69 & 14 & 803000 \\ \text { N aiset } & 18 & 64 & 18 & 796000\end{array}$

AKU95-haastattelussa valmiuksien ja työn vaatimusten suhdetta kysyttiin seuraavasti: mikä kuvaa parhaiten valmiuksianne työssänne? (1) Tarvitsette lisäkoulutusta, jotta selviäisitte hyvin työtehtävistänne. (2) Työtehtävänne vastaavat hyvin tämänhetkisiä valmiuksianne. (3) Työtehtävät ovat liian yksinkertaisia, uskotte selviytyänne paljon vaativammistakin tehtävistä. (4) Ei osaa sanoa. "Ei osaa sanoa"-vastaukset on jätetty pois analyysistä. 
tehtävien hoitamiseksi on yleisintä ylempien toimihenkilöiden asemissa ja harvinaisinta työntekijätasolla. $\mathrm{N}$ aistyöntekijöistä 8 prosenttia ja miestyöntekijöistä 12 prosenttia pitää lisäkoulutusta tarpeellisena nykyisiin tehtäviinsä. K aiken kaikkiaan reilu neljännesmiljoonaa palkansaajaa pitää työtään liian yksinkertaisena valmiuksiinsa nähden.

K un työntekijä kokee, ettei hänen jokapäiväisessä työssään ole juuri mitään opittavaa, hän on itse asiassa saanut yhden olennaisen opin työstään. Y ksinkertaiseksi organisoitu työ sekä vähäiset itsensäkehittämis- ja koulutusmahdollisuudet ovat eräänlainen viesti työntekijälle. Viestin sanoma on, että hänet on helppo korvata toisella työntekijällä ja ettei häneen ole järkevää sitoa yrityksen voimavaroja. Työntekijän liiallinen sitoutuneisuus voi olla yritykselle pikemminkin haitta kuin etu sen pyrkiessä määrälliseen joustavuuteen työvoiman käytössään. Y ritysjohdon ei ole järkevää ehdoin tahdoin tehdä tuotantoa kauttaaltaan riipuvaiseksi työvoiman hallussa olevasta osaamisesta saati antaa työntekijöiden uskoa, että he ovat yritykselle korvaamattomia. Vaikeasti korvattavat työntekijät voivat tulla vaatimuksineen yritykselle kalliiksi.

\section{Työelämä opettajana}

K oulutusta korostavat puheet ovat nykyään keskeinen osa lähes kaikkien eturyhmien edunvalvontaan liittyvää retoriikkaa. Puheet elinikäisen oppimisen ja henkisten pääomien jatkuvan kartuttamisen välttämättömyydestä sekä inmisestä työpaikan tärkeimpänä voimavarana ikään kuin pehmentävät taloudellisiin laskelmiin toimintansa perustavan elinkeinoelämän julkikuvaa. Aikuiskasvattajat ovat vastaavasti omaksuneet iskulauseet palvelemaan oman ammattikuntansa etuja.

Y rityksissä toki tiedetään, ettei koko henkilöstön jatkuvasta kouluttamisesta ole vastaavaa hyötyä. Sen sijaan puhe jatkuvan koulutuksen välttämättömyydestä saattaa olla työnantajapuolelle hyödyllistä. Y htäältä se luo mielikuvaa, jonka mukaan yritykset ovat hyvinkin kiinnostuneita henkilöstönsä koulutusasioista. Puhuminen henkilöstöön panostamisen puolesta nähdään yrityksen imagoa rakentavana kilpailuvalttina. Toisaalta taas puhe on keino kyseenalaistaa tarjolla olevan työvoiman pätevyys ja yrittää vaikuttaa sitä kautta sen neuvotteluvoimaan. Tässä diskurssissa kansalainen on työmarkkinoilla pysyvästi "epäpätevä“. Vastavalmistuneenkin kvalifikaatiot tuomitaan vanhentuneiksi tai muuten puutteellisiksi.

1990-Iuvun koulutuspolitiikassa painotetaankin entistä enemmän työelämän ja koulutuksen niveltämistä toisiinsa. Myös työelämän koulutukseen liittyvät ajattelutavat muuttuvat. K un tähän saakka on mietitty keinoja, joilla voitaisiin parantaa formaalin koulutuksen ja kurssituksen vaikuttavuutta esimerkiksi jaksottamalla koulutusta ja käytännön työharjoittelua, uuden ajattelutavan mukaan oppimisen ydin on työ ja työssä oppimisen tueksi hankitaan sopivia kursseja tai viriketilaisuuksia (Vaherva 1998).

Tätä kehityssuuntaa vasten ajatellen työvoiman entistä tarkempi eriyttäminen luottamusta nauttivaan vakituiseen ydinhenkilöstöön ja epävakaissa työsuhteissa sisällöllisesti vaatimattomia tehtäviä tekeviin nousee koulutuspolitiikan kannalta erityisen tärkeäksi asiaksi. Ajoittain työttömänä olevien ja tarpeen mukaan joustavasti tilapäistöihin kutsuttavien näkökulmasta aikuiskoulutuspolitiikan keskeinen kysymys kuuluukin: missä määrin heidän työnsä voivat olla oppimisen ja itsensä kehittämisen perustana? Moni kansalainen kun on 1990luvulla oppinut näkemään työelämän hiostamisen, nöyryytysten ja irtisanomisuhkien alla kilpailemisen kovana kouluna.

Työ voidaan toki periaatteessa järjestää monella tavalla, mutta motiivit ja voimavarat työn uudelleen organisointiin vaihtelevat yrityksittäin. Tulevaisuudessakin osa tehtävistä pidetään yksinkertaisen rutiinimaisina, jotta niihin voidaan saada nopeasti riittävän edullista työvoimaa, kun tuotantoa lisätään kysynnän kasvaessa. $\mathrm{H}$ yödykekysynnän vaihteluihin sopeutuakseen yritykset tarvitsevat entistäkin ki- 
peämmin joustavasti käytettävää puskurityövoimaa, jonka neuvotteluvoima tehtävien luonteeseen ja työsuhteen ehtoihin nähden on heikko. Kilpailun logiikka toimii tältä osin myös työ elämän kehittämisohjelmia vastaan. Työntekoa "humanisoivilla" ohjelmilla on aika vaikea muuttaa tehokkuutta ja työvoiman joustavaa käyttöä silmällä pitäen yksinkertaisiksi organisoituja tehtäviä.

Työnantajat eivät myöskään halua tehtävien sisällön ja työsuhteen laadun suhteen liian vaativia työntekijöitä häiriköimään työpaikoille. E mile D urkheimin sadan vuoden takainen kirjoitus työnjaon "epänormaaleista" muodoista näyttää pätevän olennaisilta osiltaan tänäkin päivänä:

"Joskus on eddotettu sellaista parannuskénoa, että työntekijän pitäisi teknisen ja erityistiedon lisäksi saada ylessivistystä. Mutta dettaen, että tällä tavalla parannettaisiin työnjaon viaksi luettuja haittavaikutuksia, tämä è kuitenkaan ole keino esää niiden syntymistä. Työnjaon luonne è muutu sillä, että sitä on eddtänyt yléssivistävä kasvatus. On tieđenkin hyä, jos tyäläisillä on tilaisuus kiinnostua taiteesta, kirjallisuudesta yms. Tämä on kuitenkin yhtä vää rin kuin ajatus, että häntä kohddtaisiin koko päivä kuten konetta. Kuka sitä paitsi vaisi olla tajua-matta, että nämä kaksi dämää ovat liian vastakkaisia, jotta ne vaitaisiin saattaa keske nään sopusaintuun tai samalle inmisdle mahdolliseksi dää! Jos joku ottaa tavakseen avata laajoja näköpiireä, laatia yleiskatsauksia tai hienoja ylestyksiä, hän è sen koommin suostu kärsivällisesti noudattamaan erityistehtävän ahtaita rajoja." (Durkheim 1990, 339.)

\section{Lähteet}

AALTONEN, R. 1989. Henkilöstökoulutuksen taloudellinen vaikuttavuus. Aikuiskasvatus 9 (4), $161-166$.

AKU-95. Tilastokeskuksen käyntihaastatteluina syys-joulukuussa 1995 keräämä aineisto: perusjoukkona Suomessa henkikirjoilla oleva $18-$ 64-vuotias väestö; brutto-otos 5084 henkeä; perusjoukkoon kuulumattomien vähentämisen jälkeen lopullisessa ostoksessa 5005 henkeä; hyväksyttyjä vastauksia (N) 4107 ja vastausprosentti 82.

ALTON JI, J. \& Spletzer, J. 1991. Worker characterstics, job characterstics, and the receipt of on-the-job training. Industrial and Labour Redations Review 45 (1), 58-79.

BLOMBERG, R. 1989. Cost-benefit analysis of employee training: a literature review. Adult Education Quarterly 39 (2), 89-98.

BLOMQVIST, I., Koskinen, R., N iemi, H. \& Simpanen, M. 1997. Aikuisopiskdu Suomessa. A ikuiskoulutustutkimus 1995. K oulutus 1997: 4. H elsinki: Tilastokeskus.

BOWART, N. 1996. Statistics of employee training. In A. Tuijnman (ed.) International Encydopedia of Adult Education and Training $2^{\text {nd }}$ edition. 0 xford: Pergamon, 884-888.

DURKHEIM , E. 1990. Sosiaalisesta työnjaosta. H elsinki: G audeamus.

HEIKKINEN, P. 1993. Työdämän sopimusjärjestemä ja ammatitaitckysymkset Suomessa ja viidessä mussa OECD-maassa. Työpoliittinen tutkimus 48. Helsinki: Työministeriö.

JUHELA， A. 1996. Henkilöstön kouluttamisesta työn kehittämiseen. Teoksessa J. Tuomisto \& al. Yhtéskunnan rakentet ja dinikäinen oppiminen. K asvatustieteiden laitoksen julkaisu A 59. Tampere: Tampereen yliopisto, 395-451.

JULK UNEN, R. 1987. Työprosessi ja pitkät aallot. Tampere: Vastapaino.

KALLEBERG, A.L. 1992. Job training in N orway: organizational and individual differences. International Journal of Educational Research 6 (17), 565- 579 .

LAMPIN E N , 0. 1998. Suomen koulutusäriestemän kehitys. Helsinki: G audeamus.

LEHTOSALO, L. \& Raivola, R. 1992. Koulutuspolitiikka. Porvoo: WSOY.

LEHTO, A-M. 1996. Työl ot tutkimuskdhteena. Tutkimuksia 222. Helsinki: Tilastokeskus.

LEHTO， A-M. 1998. Kiirettä työpaikoilla. Hyinvointikatsaus 2, 44- 49 .

LO WY CK, J. 1996. Learning in the workplace. In A. Tuijnman (ed.) International Encydopedia of Adult Education and Training $2^{\text {nd }}$ edition. $0 x$ ford: Pergamon, 414-418.

MOTTAZ, C.J. (1987). An analysis of the relationship between work satisfaction and organizational commitment. The Socidocigal Quarterly 28 (4), 541- 558.

MULDER, M. 1990. Training and development in organizations. An international research

AIKUISKASVATUS 4/98 


\section{ARाIKKET}

perspective. In M. Mulder, A.J. Romiszowski \& P.C. Van der Sijde (eds) Strategic Human Resource Development. Amsterdam: Swets \& Z eitlinger, 103- 119.

MULDER, M. 1992. Toward a comprehensive research framework on training and development in business and industry. International J ournal of Lifelong Education 11 (2), 139- 155.

MÄKI, T. 1964. Talouddlisen yrityksen koulutustoiminta. Porvoo: WSOY.

NAUMANEN, P. 1994. Tiedon, taidon ja vallan tielä. Miesten ja naisten kouluttautuminen ja tyä Koulutussosiologian tutkimuskeskuksen raportti 22. Turku: Turun yliopisto.

N ORDHAUG, 0. 1991. The Shadow Educational System Oxford: N orwegian U niversity Press.

OECD. 1991. Employment Outlook 1991. Paris: OECD.

RIN N E, R., Silvennoinen, H.\& Valanta, J. 1995. Työdämän aikuiskoulutus: valta, vastuu ja intressit henkilöstäkaulutuksessa. Ko ulutusso siologian tutkimuskeskuksen raportti 29. Turku: Turun yliopisto.

SI LVE N N O I NE N , H. 1998. O ppiminen työelämässä. Teoksessa H. Silvennoinen \& P. Tulkki (toim.) Elinikäinen oppiminen Helsinki: Gaudeamus, 61- 102.

SPECTOR, P.E. (1986). Perceived Control by Em ployees: A Meta-analysis of Studies Con-cerning A utonomy and Partiapation at Work. Human Relations 39 (11), 1005-1016.

TAY LO R, D. 1987. Training. In C. Molander (ed.): Personne Management. A Practical Introduction. London: Chartwell-Bratt.

TH $\AA$ N G, P.O. 1995. A mmattitaidottomat työntekijät Ruotsin teollisuudessa. Koulutusta ja oppimisen tarvetta koskevia käsityksiä. Aikuiskasvatus 15 (2), 85-92.

Tilastokeskus: henkilöstökoulutustilastot. Koulutus ja tutkimus 1989:18 ja 1992:4.; Koulutus 1993:1, 1995:3, 1997:8; julkaisemattomia tilastotietoja vuosilta 1995 ja 1996 (T. Seppänen).

TU OMIST 0, J. 1986. Tedlisuuden koulutusteltäien kehittyminen. Annales U niversitatis Tamperenesis A 209. Tampere: Tampereen yliopisto.

VAHERVA, T. 1993. Saadaanko didaktiset ja andragogiset periaatteet käyttöön työelämän aikuiskoulutuksessa? Teoksessa P. Remes (toim.): Aikuisen positiivinen koulutusvalinta: työssä vai koulussa oppiminen? Kasvatustieteiden tutkimuslaitoksen julkaisu B 78. Jyväskylä: Jyväskylän yliopisto, 119-123.
VAHERVA, T. 1995. The relevance of the entrepreneurial and personnel training. In A. Kauppi, K. N urmi, J. Tuomisto \& T. Vaherva (eds) A dult Learning in a Cultural Context $\mathrm{H}$ elsinki: Adult Education Research Society in Finland \& University of Helsinki, Lahti Research and Training Centre, 208- 213.

VAHERVA, T. 1998. Informaali ja satunnainen oppiminen työpaikalla. Teoksessa P. Sallila \& T. Vaherva (toim.) Arkipäivän oppiminen. H elsinki: K ansanvalistusseura ja Aikuiskasvatuksen Tutkimusseura, 156-177.

WHOLEY, D.R. 1990. The effectes of formal and informal training on tenure and mobility in manufacturing firms. Soidogical Quarterly 31 (19), 37- 57 .

Artikkeli saapui toimitukseen 17.6.1998. Toimituskunta teki siitä julkaisupäätöksen 1.10.1998. 